\title{
Economic growth: a panacea for child labour?
}

Article

Accepted Version

Kambhampati, U. S. and Rajan, R. (2006) Economic growth: a panacea for child labour? World Development, 34 (3). pp. 426445. ISSN 0305-750X doi:

https://doi.org/10.1016/j.worlddev.2005.08.010 Available at https://centaur.reading.ac.uk/31722/

It is advisable to refer to the publisher's version if you intend to cite from the work. See Guidance on citing.

To link to this article DOI: http://dx.doi.org/10.1016/j.worlddev.2005.08.010

Publisher: Elsevier

All outputs in CentAUR are protected by Intellectual Property Rights law, including copyright law. Copyright and IPR is retained by the creators or other copyright holders. Terms and conditions for use of this material are defined in the End User Agreement.

\section{www.reading.ac.uk/centaur}

\section{CentAUR}

Central Archive at the University of Reading

Reading's research outputs online 
Economic Growth: A Panacea for Child Labour?

\section{Authors: Uma S. Kambhampati and Raji Rajan}

Affiliation: Centre for Institutional Performance and Department of Economics, The University of Reading Business School, The University of Reading, UK.

Mailing Address for both authors: Department of Economics, The University of Reading Business School, University of Reading, Whiteknights, PO Box 218, Reading RG6 6AA.

Work Tel.: 0118378 5248/0118 9875123 ext 5248

Residence Tel. No.: 02083618782.

Fax: 01189750236

E-mail: les98usk@ reading.ac.uk. 


\section{Abstract}

In this paper, we test whether economic growth decreases child labour by bringing together data from the National Sample Survey of India and state-level macro data to estimate a bivariate probit model of schooling and labour. Our results lead us to conclude that contrary to popular wisdom, growth actually increases rather than decreases child labour because it increases the demand for child workers. The level of state NDP, village wages and household incomes are seen as the conduits through which growth influences the supply side of the child labour market.

Keywords: Child labour, Schooling, Growth, Kuznets curve, Pro-poor growth, Asia, India 
Acknowledgements: We are grateful for comments from participants of departmental seminars at the Universities of Reading and Birmingham and to Marina Della Giusta for comments on an earlier version of this paper. We would like to thank the referees of this journal for extremely constructive comments, which have helped to improve the paper considerably. Finally, we would like to thank the Department for International Development, UK, for funding the project that made this research possible. 


\section{Economic Growth: A Panacea for Child Labour?}

Does growth decrease child labour? Much long range historical and cross-country evidence seems to suggest that it does. Clearly, child labour participation rates have decreased in almost all countries over time. International evidence also indicates that the labour participation rates of children have decreased across the world between 1950 and 2000 (see Table 1). The decline has been significant in all regions of the world, bringing the world average down from $27.6 \%$ in 1950 to $11.3 \%$ in 2000 . In Europe, the fall has brought the child labour participation rate down to $0.04 \%{ }^{1}$ and even in India child labour participation rates decreased from $35.43 \%$ to $12.07 \%$ during this period.

\section{Insert Table 1 here}

More detailed regional and historical evidence, however, seems to suggest that economic growth has led to increasing child labour participation. Thus, Swaminathan (1998), studying child labour in a fast-growing region of India finds an increase in the numbers of children employed. Heywood (1988) also argues that the early phase of industrialisation in the UK brought an increased reliance on child labour. In this paper, we will analyse this relationship between the rate of growth of an economy and the extent of child labour that exists within it.

The impact of macroeconomic performance on child labour and schooling has attracted considerable attention in the literature (Grootaert and Patrinos, 1999; Swaminathan, 1998; Barros et al, 1994; Neri and Thomas, 2001; Kak, 2004; Weiner, 1991). This paper adds to this literature by testing the relationship empirically across an extensive dataset -- Schedule 50 of the National Sample Survey of India. This data is particularly appropriate in the context of our analysis covering as it does about 15 major states, each with very varied macroeconomic performance and sociocultural environments. In addition, the federal nature of many of India's institutions and the uniformity of data across the country facilitate our analysis. 
The paper makes two main contributions to the literature. First, it attempts to separate out the determinants of the supply of child labour from the demand for child labour. Basu et al (2003) state that 'the demand side factors (of child labour) are not observable and have earlier been ignored' so that 'all the data available to us as well as those used in earlier empirical studies on this topic relate to the supply side of child labour' (Basu et al, 2003, p.11). They attempt to correct for this by including village level fixed effects which proxy for the impact of regional prosperity on household incomes, infrastructure and on opportunities for employment. In this paper, we separate out these different effects by including average village wages, state level net domestic product (NDP), state growth rates and the contribution of agricultural production to the NDP of each state. Some of these factors - average village wages and state level NDP - proxy for the effect that the regional environment may have on household income or in providing better facilities for schooling. Thus, they influence the supply side of the child labour market. Other factors - state growth rates and the proportion of agricultural production in the NDP of each state - on the other hand, are more likely to influence the demand that might exist for child labour. Thus, NDP growth (as we will see below) is likely to increase employment opportunities and in a rural economy, these are likely to be for relatively low-skilled farm jobs, which children can easily fill. It has often been argued that children are more likely to work on family farms than in industrial enterprises (Lieten, 2002; Bhalotra and Heady, 2003; Basu et al, 2003) and we have included the agricultural intensity of a state's output in our analysis to capture this effect.

Second, our analysis in this paper enables us to investigate whether macroeconomic growth may be expected to decrease child labour, as is often argued. With child labour being popularly considered to result from poverty, many policy makers, reviewing international evidence (see Table 1), argue that the best panacea for child labour is economic growth (see Weiner (1991) for the context in which this argument is put forward in India). Our results reject this straightforward conclusion. 
They indicate that growth has an inverted U-shaped relationship with child labour wherein child labour initially increases with growth and subsequently declines. We will consider this pattern in the rest of this paper.

Before we do this, we will consider the relationship between growth and child labour in more detail in the next section.

\section{THE GROWTH-CHILD LABOUR RELATIONSHIP: A CHILD LABOUR - KUZNETS}

\section{CURVE?}

As mentioned above, economic growth will have an effect both on the demand for, and supply of, child labour. Any impact that it has on supply must work through its effect on household incomes, regional infrastructure and schooling facilities, all of which will influence the household's motivation to send children out to work. To separate out this effect (on supply) from the impact that growth will have on the demand for labour, we include variables like average village wages, state NDP per capita and household incomes that will directly capture these supply side effects. Once the effect of these variables has been separated, we may expect that any residual impact that economic growth has will be through its impact on the demand for child workers rather than on their supply. Let us consider each of these in turn.

To begin with, economic growth may be expected to increase household incomes either because it increases adult wage rates or because it creates more employment opportunities for adults. However, this effect will only hold if growth is pro-poor and if children are sent to work because of poverty to begin with ${ }^{2}$. Insofar as these two conditions hold, however, growth may be expected to decrease the supply of child workers to the labour market, an effect that will be mediated through household wages and incomes and therefore will be more directly captured by including them in our analysis. 
It is possible that growth exerts two further influences on a family's decision to send a child to school rather than to work. On the one hand, higher growth could imply a higher return to education increasing the incentive for parents to send their children to school. On the other hand, growth may also imply that future generations will be better off than the current generation. The current adults in a family may therefore want to shift resources back in time and child labour may be one way to achieve this ${ }^{3}$.

In addition to its impact on household incomes, growth will also increase the level of NDP of a state and the latter will proxy for a number of supply side influences. First, a prosperous economy may be one which has strong and binding rules regarding child labour and schooling; rules which make it compulsory for children to be enrolled in school and more important, to attend school, once enrolled. Second, prosperity may create a socio-cultural environment in which children are seen not only as an economic asset but also in terms of their emotional and psychological contribution to the household. In this context, the quality of children becomes significant, leading parents to value school attendance. Third, prosperity may result in better infrastructure with regard to schools so that parents no longer feel that school is a waste of time or that their children are likely to benefit more in the long run from work experience (Grootaert and Patrinos, 1999; Dreze and Gazdar, 1996). Fourth, prosperity may help improve the socio-cultural environment so that school attendance becomes a norm rather than dependent on choices made by parents. All these factors will influence the supply of children to the labour market. In our analysis, these factors will be captured by average village wages and the level of NDP of the state in which the child lives.

To summarise, we may say that the impact that growth has on the supply of children to the labour market will be mediated through the level of state NDP per capita (proxy for regional prosperity), 
average village wages (proxy for village prosperity) and household income levels (proxy for household prosperity).

However, this is only part of the story. Once the impact of growth on household and regional prosperity is allowed for, the residual impact of growth will be on the demand for child workers. As the economy grows, the labour demand curve will shift to the right both for adults and children. Initially, the jobs that become available, especially in the rural sector, will be low-skilled jobs. Eventually, however, as the economy continues to grow, the supply of low-skilled jobs dries up and sustained growth will result in an increase in high-skilled jobs both in the agricultural and industrial sectors. This, in turn, will increase the demand for schooling and decrease child employment. It is therefore expected that the impact of growth on the demand for child labour will be quadratic, with an initial increase in demand and a longer term decline. This growth-child labour relationship could be termed the child labour-Kuznets curve - an inverted U-shaped relationship wherein growth will initially increase child labour by increasing the opportunities for low skilled employment but will eventually lead to a shift towards more skilled workers. In this context, the pertinent question, of course, is the income level at which growth actually begins to decrease child labour.

Our analysis so far leads us to conclude that the impact of economic growth on the supply of children to the labour market is likely to be linear and negative and to be captured in our specification by more proximate prosperity variables like NDP and village wages. The impact of growth on the demand for labour, on the other hand, is likely to be quadratic with a maximum. We therefore include growth and the square of growth in our model specification. It is possible that the initial impact of growth will be on increasing demand for child workers, especially in the context of extreme poverty. Over time, however, sustained growth will be reflected both in a decrease in demand for child workers (who are no longer sufficiently skilled) and in a decrease in the supply of such workers (because household incomes and regional prosperity improves). The net effect will 
also be quadratic, with the initial increase in child work being followed by a decrease in the longer run.

\section{LITERATURE REVIEW}

There is considerable historical evidence in support of such a quadratic relationship. Thus, Heywood (1988) argues that 'there is evidence, then, that the early phase of industrialisation, during the $18^{\text {th }}$ and $19^{\text {th }}$ centuries, brought an increased reliance on child labour,' (Heywood, 1988; p.132). The subsequent reversal in this trend is also clearly documented by historians, though the precise timing of this reversal is controversial. Nardinelli (1990), for instance, argues that while children under 13 years were $20 \%$ of the labour force in the cotton textile industry in 1816 , they were only $13.1 \%$ by 1835 . Similarly, Heywood (1988) claims that while $30 \%$ of $10-14$ year olds were employed in 1851 , this had decreased to $17 \%$ by 1901 . Such a pattern was common to most Western economies at the time.

The reasons, both for the initial increase and later decline, in child labour participation rates in Great Britain have pre-occupied many researchers. Horrell and Humphries (1995) suggest that since child labour increased in those families where the father's wages were also increasing, one must conclude that children worked where there were opportunities for such employment. And the opportunities to employ children did increase, at least initially, because 'women and children are rendered more useful, and the latter more early useful, by manufacturing establishments, than they otherwise would be,' (Alexander Hamilton quoted in Heywood, 1988: p.129). A similar point was made by Marx who argued that with the rise of new technology, especially machinery, 'there is scope for employing those whose bodily development is incomplete and whose limbs are all the more supple,' (Basu, 1999: p.372). In fact, Horrell and Humphries (1995) argue that in the initial stages of growth, families were often constrained to supply less child labour than they considered optimal. With growth, such constraints were loosened and families were able to access a wider 
range of livelihood options. Child work therefore increased. Over time, however, an increase in adult wages and living standards, the success of regulation (e.g. the Factory Acts), compulsory schooling, income growth and other factors all helped to decrease child labour in Britain.

Swaminathan (1998) in a study of a prosperous and fast growing region of India - Gujarat - finds that child labour has increased. The study relies on detailed primary evidence and Swaminathan does not attempt to test the strength of the relationship formally. Cigno, Rosatti and Guaracello (2002), analysing the impact of globalisation on child labour using a large sample of developing countries, find that the problem is not so much globalisation or trade exposure as being allowed to take part in trade. Kak (2004) considering the relationship between the level of development of Indian states and the incidence of child labour amongst 10-14 year olds, clearly concludes that it is not a 'monolithic or linear relationship'. In fact, a simple correlation coefficient (calculated from Kak's own figures) of the proportion of rural (10-14 year old) boys in the labour force and the HDI rank of the state is 0.2181 . This is low and confirms his argument that the level of development is only one factor determining the extent of child labour in a state. Torres (nd), however, analysing the relationship between a country's growth and its child labour at a macroeconomic level, finds that an increase in growth leads to a decrease in child labour.

Grootaert and Patrinos (1999) argue that 'primitive technology can create situations in which adults cannot substitute for children.' This includes boys used in mine tunnels that are too small for adults to crawl through or used as chimney sweeps. In this context, changes in technology helped to decrease child labour. In their analysis of child labour in a number of countries, Grootaert and Patrinos (1999) include regional dummies as a weak proxy for demand side factors.

Kak (2004), in a study of child labour in India, tries to explain the 'persistence of child labour in a period when unemployment levels for adult workers are increasing'. He argues that the demand for 
children in the labour market occurs not because of labour shortages but because of the characteristics of the labour market which is segmented by caste, gender and class divisions and 'which provide distinct spheres for participation of children in the labour force' (Kak, 2004, p.46). 'Children - working in fields, or grazing cattle, winnowing paddy - are not only an extra hand for their families but also relieve the adult labour to seek employment away from villages' (Kak, 2004, p.45). In this context, Chandrasekhar (1997) argues that an abolition of child labour is likely to lead to an increase in adult wage rates.

Myron Weiner (1991), in a break from the rest of the literature, argues that child labour in India arises not so much from India's low per capita income and poor economic situation, as from a 'set of beliefs, that are widely shared by educators, social activists, trade unionists, academic researchers and more broadly, members of the Indian middle class' that education is a means of maintaining differentiation amongst the social classes and excessive and inappropriate education for the poor would disrupt existing social arrangements' (p.5). Weiner articulates the official Indian position that as employment and incomes increase, it will no longer be necessary for the poor to send children to work or that as technology changes, the demand for unskilled workers will decrease and therefore parents will send children to school (p.13). In a detailed socio-political study, Weiner concludes that such explanations 'do not stand up against historical and comparative evidence' (p.14) from other countries.

\section{DATA AND METHODOLOGY}

\section{Data}

The data for our analysis are from the 50th round of the household socio-economic survey conducted by the National Sample Survey Organisation in India. The dataset is large and complex, and covers all the states and Union Territories in India. It includes socio-economic information for 356,352 individuals belonging to 69,231 households in rural India. Since this round of the survey 
was focussed on consumer expenditure and employment and Schedule 10 itself concentrates on education and employment issues, we have detailed information on the educational status and economic activity of members of each of the households in the survey for 1993. The dataset thus provides us with exhaustive information on the work and schooling status of children in these households, and the educational and employment status of their parents. For the macro variables, we used a variety of sources including the Economic Survey and the Dutt and Ravallion data from the World Bank web site.

Children in this study have been defined as those between 5-15 years of age, a definition that conforms to the less-strict definition put forward by the ILO and UNICEF ${ }^{4}$ (ILO, 1996). Since the paper focuses on child labour, the under-5 category was not considered. This provides us with a sample of 93,825 children around whom the analysis in this paper is concentrated. Tables $1 \mathrm{a}$ and $1 \mathrm{~b}$ in Appendix 1 provide summary statistics of the binary variables (Appendix 1a) and continuous variables (Appendix 1b) used in the analysis in this paper. The statistics indicate that $65 \%$ of children state their principal activity as going to school $(\mathrm{SCHOOL}=1)$ and $7.14 \%$ as Work. $46.4 \%$ of the sample children are girls and the average age of children in the sample is 9.77 years.

Though the data from the NSS is rich and comprehensive, as far as such household data sources go, some limitations with regard to their measures for child work need to be kept in mind. In the rural sample that is the concern in this paper, the tasks undertaken by children are likely to be highly seasonal and can be undertaken together with schooling. Therefore, there is some ambiguity when the principal and secondary activity status of children is being recorded (Kak, 2004, p.50). In addition, of course, the work done by girls within the household is much harder to determine precisely. There is also likely to be some under-reporting of child work because of attempts to take advantage of the mid-day meal scheme in schools (Kak, 2004). 
India provides a good example with which to test the effects of growth and development on child labour because the initial level of incomes as well as the growth of these incomes varies across states. Equally important, the levels of development also vary significantly across states. Thus, there are states like Kerala, which have relatively high levels of human development. On the other hand, there are states like Bihar and Madhya Pradesh where the levels of human development are significantly lower. Before we go any further, let us look at the regional spread of child labour in India.

\section{Insert Table 2 here.}

The above table indicates that child labour is highest in Andhra Pradesh and lowest in Kerala. Surprisingly, we find that the poorer states (Bihar and Uttar Pradesh (UP)) also have relatively low rates of child labour participation. Looking further, we find that some states like Tamil Nadu have both high child work and high child schooling participation whereas others (Bihar, MP) with low child work have low schooling figures too. In these states, therefore, low child labour seems to reflect 'low opportunity'.

\section{Methodology}

To consider the impact of economic growth on the probability of a child being employed, we analyse the determinants of work and schooling within a standard bivariate probit model. Within this framework, SCHOOL and WORK are our two binary dependent variables and they are specified according to the principal activity status of the child (see Appendix 1). Child work is said to occur when the principal activity of the child refers to any one of those activities, which are categorised as 'employed' within the data. Here the dependent variable WORK is coded 1 if the child is working, else is coded 0 . When the principal activity of the child refers to attending educational institutions the child is categorised as going to School. Here the dependent variable SCHOOL is equal to 1 if the child is going to school, else is coded 0 . This classification is based on self-reporting of activities ${ }^{5}$. 
Although our primary concern in this paper is the influence of regional growth and development on the probability of child work, we control for a number of personal characteristics (including age and sex of the child) and household characteristics (like mother's and father's education and employment status, household religion, landownership and debt status). The definition of each of the variables included in the model is in Appendix 1. We will therefore not describe these variables in much detail in what follows.

\section{Personal and Household Characteristics}

We include age (AGE) and the square of age $\left(\mathrm{AGE}^{2}\right)$ of the child in both equations. We expect that as children grow older, they are more likely to participate in the labour market. We also include Sex ( $0=$ boys $)$ in our model. In general, it is expected that girls are less likely to be involved in economic activity than boys but also less likely to participate in schooling. This is because girls are more likely to be involved in domestic chores than boys and spend a significant proportion of their time in such activities. While analysing these activities of girls is beyond the scope of this paper, they have been analysed in some detail by Kambhampati and Rajan (2004b). In this paper, we concentrate on the market activity of girls rather than on domestic work, whilst accepting that this will provide an incomplete picture of their work loads. Since preliminary tests indicate that it is not only the work participation rates that vary across boys and girls but also the determinants of such work, we estimate the model separately for boys and girls.

In addition to the variables capturing the child's personal characteristics, we include a number of variables that allow for mother's and father's characteristics. Thus, we include father's and mother's education into our model as 3 separate binary variables, each representing different levels of education - primary, secondary and tertiary - EDUPRI, EDUSEC and EDUTER. In general, it is expected that better educated parents have greater ability and incentive to improve their children's 
education and therefore are less likely to send them to work at an early age. Summary statistics (see Appendix 1) indicate that $14 \%$ of fathers in our sample have primary education, $11 \%$ have secondary education and only $3 \%$ have tertiary education. Amongst mothers, the proportion who are educated is lower $-7.4 \%$ have primary education, $5 \%$ have secondary education and less than $0.6 \%$ have tertiary education.

The literature also argues that the employment status of parents is important. It has been argued that mothers who are employed (MOTHER_WORK) are likely to be more broad-minded about their daughter's employment and education prospects than those working only within the household. There is, however, some disagreement regarding this, with some evidence (see Basu, 1993) that working mothers are more likely to withdraw their daughters from school so that they can help at home and outside. To consider these effects, we include two variables (FATHER_WORK and MOTHER_WORK) reflecting the mother's and father's employment status into our model. While $91 \%$ of fathers stated that they worked more or less regularly (FATHER_WORK), less than 35\% of mother's claim to work regularly (MOTHER_WORK) (see Appendix 1).

Other variables that are included in our model are dummies for religion, social group, household debt and landownership. HINDU and MUSLIM are categorical variables that identify Hindu households and Muslim households relative to all others. With Hindu children being $84 \%$ of our sample (see Appendix 1), the non-Hindu category (including Muslims, Christians, Sikhs, Jains, Buddhists, Zoroastrians and others) is approximately $16 \%$. On the other hand, the non-Muslim category is $89 \%$ (and includes Hindus and the other non-Muslim religions mentioned above). We also include the social group of the household (SOCGROUP), which is 1 if the household belongs to a scheduled caste or tribe and is zero otherwise. Approximately $27.8 \%$ of children within our sample belong to scheduled caste and tribes (see Appendix 1). We would generally expect that schooling would be less amongst these groups and work would be higher. 
Household debt (DEBT) is included to see whether households that are in debt are more likely to send their children out to work or not. Many studies argue that cash flow problems provide the initial catalyst for households to send children out to work. However, once this is done, they find it hard to reverse the decision. Our summary statistics (Appendix 1) indicate that $11.6 \%$ of children live in households that hold some debt. We also include a variable that identifies households which own land relative to those that do not (LAND). It has long been argued that land ownership (LAND) can have conflicting effects on child work - on the one hand increasing the opportunities for child employment (i.e. the demand for child workers) and on the other, increasing household wealth and therefore decreasing child employment (Bhalotra and Heady, 2003) i.e. the supply of child workers. In the context of the girl child, however, it could also reflect a relatively conservative feudal environment (Admassie, 2003) in which girls are more likely to be retained at home rather than sent out either to work or to study. Landowning households are likely to be more patriarchal than others. Appendix 1 indicates that approximately $96.6 \%$ of our sample children live in households that own some land.

Finally, we include parent labour income [mother's + father's wages] in our School and Work equations as the variable PARWAGE. On average, weekly parental wage within our sample is Rs.93.4 and the standard deviation of this wage is Rs.190.5. Given the luxury axiom, this variable might be expected to significantly influence the supply of child labour. We hypothesise that the higher are the wage variables, the higher is the probability that children go to school rather than work. In addition to this wage variable, we also include a variable (OTHINCOM) that captures all the other sources of household income. This variable is included to allow for incomes earned by the family from non-labour sources. It can be significant in cases where parents work but do not earn an income because they work in a family enterprise, for example. It can also be significant where the family earns significant rental or other income. This variable is total monthly household 
expenditure $^{6}$ minus PARWAGE minus child wages. The summary statistics in Appendix 1 indicate that this is a major part of the household's income. While the parent's wage income is Rs.93.34 per week on average, OTHINCOM is Rs.1846.17 per month (i.e. Rs.461.54 per week).

\section{Prosperity, Growth and Child Labour}

In addition to the above personal and household characteristics, we include a number of variables that reflect the prosperity of the region that the child lives in. These include the NDP of the state, average village wages, the growth rate of the state, the pro-poorness of its growth and the proportion of NDP contributed by agriculture. Let us look at each of these in turn.

SNDP is the state's NDP per capita and is expected to proxy the prosperity of the state. Since we have included household income separately, the state NDP per capita will allow for the fact that the very poor in a poor state are doubly disadvantaged - both because they are poor and because they live in a poor state. As indicated earlier, it will reflect the infrastructural and institutional arrangements in a state and therefore will influence the supply of child labour. We also include average village-level wages (VILPROS) into our model to proxy for village prosperity. This variable is calculated from within our sample and is the only village level variable for which we have information. The higher are village wages, the more prosperous the village and the lower the probability of child labour in such villages. Our summary statistics (Appendix 1) indicate that the average weekly village wage within our sample is Rs.132.48, with a standard deviation of Rs.94.86.

The distributive impact of growth on the poorest households is captured by the PRO-POOR variable. As indicated earlier, one of the factors that might determine whether growth increases or decreases child work could be the extent to which the benefits of this growth are equitably distributed. The pro-poor variable proxies for this by taking the average decrease in poverty for every $1 \%$ increase in NDP across the country (calculated by Datt and Ravallion, 1998). We then 
calculate the actual reduction in poverty per $1 \%$ of growth in each state. The PRO-POOR variable is the difference between the actual reduction in poverty in each state and the average reduction across India for every $1 \%$ of growth. States that were above the All-India average were considered to be pro-poor because their growth had a larger impact on decreasing poverty as compared to the Indian average. Thus, this variable, together with the level of NDP per capita will capture the impact that growth has on the supply of child labour.

On the demand side we include the rate of growth of NDP (GROWTH) in each state. As indicated earlier, the impact that economic growth may have on the supply of child labour works through state NDP per capita and household incomes, which have been included separately in our model. In this specification, therefore, the growth of NDP may be expected to influence only the demand for child labour. Initially, an increase in economic growth is likely to shift the labour demand curve to the right and therefore to increase employment opportunities both for adults and children. Households that were previously constrained by the availability of jobs will now be able to send their children out to work. Over time, however, we expect that sustained increases in growth will lead to an increase in the demand for skilled labour and a decrease in the demand for unskilled children in the labour market. This will result in an inverted U-shaped relationship between growth and child labour. We therefore include growth as a quadratic term, to capture both the initial increase and the later decrease. Average state-level growth rates in our sample are $62.4 \%$ over the period 1982-1992, with a minimum of $37.81 \%$ in Bihar and a maximum of $97 \%$ in Rajasthan (see Appendix 1).

In an alternative specification (see Table 6), we also include growth interactively with NDP to allow for the fact that the impact of growth will be different in states with low, medium and high NDP. Thus, it is possible that growth in low NDP states will cause an increase in demand for child labour, while in high NDP states, growth may increase the demand for skilled adult labour but not for 
children. The variables (GROWTH*NDPL, GROWTH*NDPM, and GROWTH*NDPH) in the estimations in Table 6 are growth interacted with low, medium and high NDP respectively. Growth in low NDP states (GROWTH*NDPL) is $23.85 \%$, while it is $24.05 \%$ in medium NDP states (GROWTH*NDPM) and $14.5 \%$ in high NDP states (GROWTH*NDPH) (see Appendix 1). However, the need to impose discrete cut-off points for high, medium and low NDP states makes these results more prone to bias than those in Table 3 . We therefore concentrate on the results in Table 3 in the next section though a quick look confirms that the results from this specification are very similar to our main specification, further reinforcing the robustness of our main results.

Another variable that is likely to influence the demand for children in the rural labour market is the proportion of agriculture in the state's NDP (PROAGRI). Children in rural areas are often employed on family farms because labour requirements in this sector are both casual and seasonal. In-family child workers fulfil both requirements while also decreasing the supervision required and therefore decreasing the moral hazard problems in agriculture (Bhalotra and Heady, 2003). Admassie (2003) has found a strong positive correlation between the incidence of child labour and agriculture's share in NDP. He argues that 'backward and labour intensive' production processes (like agriculture) are especially intensive in their use of child labour. In 1991, 46\% of rural child workers in India were engaged as agricultural labourers. According to the 1991 Census, around $42 \%$ of children worked on their family farm in agriculture and in animal husbandry and fishing respectively (Lieten, 2002). Overall therefore we may expect this variable to increase the demand for child workers ${ }^{7}$. Across the 15 states that we include in our analysis, the proportion that agriculture contributes to state NDP is $32.6 \%$ on average, with a minimum of $18.4 \%$ in Maharastra and a maximum of $45.3 \%$ in Punjab. 


\section{DISCUSSION OF RESULTS}

Our results indicate that there is a significant difference in the factors influencing the probability of employment of boys and girls. The likelihood ratio test of this difference gives a calculated chisquare statistic of 1582.96 , which is highly significant and leads us to reject the hypothesis that the same model could explain the probability of employment of both boys and girls. We therefore present the separate results and discuss the differences as we go along.

\section{Insert Table 3}

Though the results for both schooling and work are presented, our discussion will concentrate only on the factors influencing the probability of work. From time to time, of course, we will consider the results for schooling because they help confirm patterns with child employment. We will also consider both the coefficients and marginal effects of the estimates that we have obtained (see Table3).

As indicated earlier, personal and household characteristics will in general influence the supply of labour, as will certain macro variables like village wages (VILPROS), the state's NDP per capita (SNDP) and the pro-poorness of growth (PRO-POOR). Other factors like the rate of growth of NDP (GROWTH) and the agricultural intensity of the state's output (PROAGRI) are hypothesised as more likely to influence the demand for child workers. We will discuss these in turn.

The probability of working for both boys and girls initially increases with age (AGE) though at a decreasing rate. Our results indicate that Muslim (MUSLIM) boys and girls work less than those from other religions. While the marginal effect for Muslim boys is very close to that of Hindu boys (-0.03), that for Hindu girls is significantly higher than for Muslim girls. We can therefore conclude that the probability of work for Hindu and Muslim boys is very similar but, surprisingly, the probability of work for Hindu girls is higher than for girls from other religions. Interestingly, we find that both Hindu and Muslim girls have a lower probability of going to school than their 
brothers. Our results also indicate that children from scheduled castes and tribes $($ SOCGRP $=1)$ have a higher probability of being employed than children from other social groups. Once again, the magnitude of this coefficient for boys is double (0.024) that of girls $(0.012)$.

As expected, father's and mother's education at all stages - primary, secondary and tertiary (FEDUPRIM, FEDUSEC, FEDUTER \& MEDUPRIM, MEDUSEC, MEDUTER) - decreases the probability of both boys and girls working. The only exception to this is mother's tertiary education, which has an insignificant impact on the probability of work for children. We see that the relationship is clearly increasing monotonically. Thus, while the marginal effect of primary education of fathers on girl's work is 0.007 , the marginal effect of secondary education is 0.022 and of tertiary education is 0.027 indicating that as the level of father's education increases, girl's employment decreases monotonically. This is true, and more significantly so, for boys. The effect of an increase in mother's education is less clearcut. Mother's education clearly decreases the probability of employment of both boys and girls. However, for boys, the impact of mother's primary education is particularly large (a marginal effect of -0.068) as opposed to secondary education (-0.055). For girls, both the primary and secondary education of mothers is significant (0.029 and -0.034 respectively).

While mother's employment (MOTHER_WORK) significantly increases the probability of daughter's employment, it has no significant impact on the probability of boy's employment. This complementarity between mother's work and daughter's employment has been commented on elsewhere in the literature (Ray, 2000; Kambhampati and Rajan, 2004b). Father's employment (FATHER_WORK), on the other hand, does not particularly influence the probability of work for either boys or girls. 
We find that an increase in parent's wage earnings (PARWAGE) decreases the employment of both boys and girls. The marginal effect is larger for boys (-0.0001) than for girls $(-0.00003)$. While these coefficients may seem small, they indicate that an increase in parent wages by Rs.100 would decrease the probability of boy's employment by $1 \%$ and of girl's work by $0.03 \%$. This finding clearly confirms the luxury axiom in our sample. We also find that an increase in OTHINCOM of Rs.100 decreases the probability of both boy's and girl's work by $0.1 \%$ approximately. Overall therefore, our results relating to wages and incomes confirm the luxury axiom - households would not send their children out to work if the income from non-child labour sources was sufficiently high (Kambhampati and Rajan, 2004a).

\section{Impact of Macroeconomic Prosperity}

Turning now to the impact of the macroeconomic variables on the probability of child labour, we find that as expected, the probability of child employment is lower in states with higher NDPs (SNDP). The marginal effect for girls is larger than that for boys leading us to conclude that the externality effect of a prosperous environment has a pronounced impact on child work. As discussed earlier, this might be because greater prosperity may be associated with better infrastructure, compulsory schooling, better schools and/or a more progressive socio-cultural environment in which schooling is a norm. At a more localised level, we find that an increase in average weekly village wage (VILPROS) by Rs.100 decreases the probability of employment for boys by $2 \%$ and of girls by $1 \%$.

We hypothesised that it is not so much the level of macroeconomic output as changes in this output that are relevant for the prospects of child labour. We therefore included both growth in NDP (GROWTH) and the pro-poorness of this growth (PRO-POOR) into our analysis. Our results indicate that, as hypothesised, growth has a strong and significant quadratic effect on the probability of work both for boys and for girls. Once again, however, it increases the probability of 
employment of boys more (a marginal effect of 0.011 ) than of girls $(0.009)$. Thus, a $1 \%$ increase in growth increases the probability of employment of girls and boys by approximately $1 \%$. Our results confirm that the probability of employment first increases and then decreases, confirming a Kuznets type relationship. Households in India seem to be demand-constrained in the amount of employment that their children undertake. An increase in growth rates lifts this constraint and draws more children into the labour market. Only when this is sustained over time will it result in a decrease in the employment of children.

Our results also indicate that the pro-poorness of growth (PRO-POOR) does not significantly influence the probability of employment of boys. For girls, however, pro-poor growth actually increases the probability of employment quite significantly. This is surprising because we would expect that when growth is pro-poor it would help to decrease child employment. From our results, however, it seems to be the case that when growth is pro-poor, the opportunities for employment increase because the opportunities are well-distributed and this increases the employment of girls.

The other macroeconomic demand variable that we included was the agricultural intensity of production of state NDP (PROAGRI). We expected this to increase child employment because there are more opportunities for the casual employment of children on farms. Our results are extremely interesting. We find that the probability of employment of boys increases significantly in agricultural states reinforcing the findings of Lieten (2002). However, the probability of employment of girls decreases significantly, reinforcing the argument of Admassie (2003) that agricultural regions or households are likely to be more conservative regarding the role played by girls/women. Our results also indicate that children have a higher probability of being employed in the more rural and agricultural states reinforcing the argument that rural activities provide more opportunities for the employment of children (Lieten, 2002). 


\section{Predicted Probabilities}

\section{By State}

Our main aim in this paper was to consider whether differences in growth and development across Indian states are reflected in child labour participation rates in these states. In this section, we will consider how the estimates of the probability of child labour vary across states in India, by calculating the probabilities predicted by our model when holding each variable at its state-level average (see Table 4).

\section{Insert Table 4}

We find that the average probability of child work across states in India is 0.026 for both boys and girls. The probability is higher for boys (0.028) than for girls $(0.020)$, as expected. Considering the states separately, we find that Rajasthan has the highest probability (at 0.072 ), followed by Orissa (0.042). States such as Kerala (0.005), Punjab (0.009), Bihar (0.016) and Maharashtra (0.018) have the lowest probabilities. At first glance, these results are surprising because Bihar (a relatively lowdevelopment state) emerges as one with relatively low child labour. This confirms our earlier argument that there are two possible low child labour positions, one associated with a relatively 'developed' economy like that of Kerala and the other with an economy that is much less prosperous and developed. In the former, low child labour occurs because households are well-off and opportunities for education exist. In the latter, low child labour occurs because even though households are poor, economic opportunities for employment are few. In the latter case, currently existing rates of child labour are demand-constrained rates, implying that the unconstrained figures may be significantly higher than these rates. This is further reinforced by the fact that schooling probability in low child labour states like Bihar and Orissa is also very low, indicating that these really are the 'low opportunity' states.

Considering Kerala and Bihar in more detail, we find that the probability of work for boys is higher in Bihar (0.024) than in Kerala (0.008) though the probability of employment for girls is very 
similar in the two states. What makes Kerala (a high development state) different from Bihar (a low development state) is the probability of child schooling. In Kerala, the probability of child schooling is 0.898 and it is higher for girls (0.904) than for boys (0.898). In Bihar, on the other hand, the overall probability of child schooling (0.539) is much lower and the probability for girls is 0.387 , the lowest in India. Thus, while both states have similar levels of child employment, this arises from very different circumstances. It therefore leads us to conclude that while further growth is likely to decrease child labour in Kerala, it may well increase child labour in Bihar at least in the first instance.

Analysing the probabilities separately for boys and girls, we find that the lowest probability for girl's work is in Punjab (0.001) and the highest probability is in Rajasthan (0.102). The highest probability predicted by our model for boy's employment is in Orissa (0.046) and Karnataka (0.040) while the lowest probability is in Kerala (0.008) and Tamil Nadu (0.000).

\section{By Variable}

We now consider the impact that an increase (or decrease) in variables reflecting macroeconomic prosperity would have on the probability of child work. Thus, we consider the impact that having a certain level of NDP, growth or the proportion of agricultural output in the state's NDP, for instance, would have on child employment. Our results are presented in Table 5.

\section{Insert Table 5}

Table 5 clearly indicates that if all states in India were to grow as fast as the fastest growing state, then the probability of child labour more than doubles (to 0.063). This leads us to conclude that the existing child labour participation in India is constrained by demand (rather than supply) side factors. As growth increases and loosens the demand side constraint, more and more families take the opportunity to send their children out to work. The probability of girl's employment increases from 0.02 to 0.103 and that of boy's employment from 0.028 to 0.033 . It would take a considerable 
increase in growth to raise incomes sufficiently to decrease supply of children to the labour market. This can perhaps be seen from the effect that higher NDP would have on child employment.

Looking at Table 5, we find that if average NDP across the country were to increase to the level of the richest state (Punjab), then the probability of child work would decrease to one-third that of the current all-India average $(0.008$ as against 0.026$)$ while the probability for girls would decrease to one-tenth (0.002). Again, the more than proportionate decrease in girl's employment relative to boys is evident from our results. If NDP were to be held at the level of the poorest state (Bihar), the probability of child labour almost doubles from 0.026 to 0.046 .

In the states where agriculture makes a larger contribution to the economy (Punjab), the probability of child employment (0.036) is more than the Indian average. When the agricultural intensity of production is lowest, the probability of work decreases to 0.018 . We also note that the probability of employment of girls in agriculture-intensive states is below the average probability across the country (i.e. 0.019 as opposed to 0.020 ), while the probability of employment of boys in agricultural states is higher than their all-India average (0.036). Pro-poor growth increases the probability of work for girls (to 0.023 ) above the general average.

\section{CONCLUSION}

In this paper, we have considered the impact that macroeconomic growth and development may have on the probability of child labour within households. Our analysis brings together data from schedule 10 of the $50^{\text {th }}$ Round of the 1993 National Sample Survey of India and state level macro data from various sources. Our main concern was to test popular wisdom -- that improved growth would decrease child labour. We test this by estimating a bivariate probit model to analyse the probability of work and schooling for boys and girls across 15 states in India. 
Our results lead us to conclude that contrary to popular wisdom, growth actually increases rather than decreases child labour. It is only when growth is sustained that it might help to decrease the supply of child labour sufficiently to offset the impact of increased demand. Our results therefore lead us to trace out a child-labour Kuznets curve. We interpret this as the impact of growth on the demand for child workers. Another factor influencing the demand for child workers (the agricultural intensity of state NDP) is also found to be significant. The level of state NDP, village wages and household incomes are all highly significant and decrease the probability of child work. These variables are seen as the conduits through which growth influences the supply side of the child labour market. Contrary to expectations, the pro-poorness of growth also seems to increase the probability of work, especially for girls. 


\section{BIBLIOGRAPHY}

Adamssie, A. (2003). Child labour and schooling in the context of subsistence rural economy: Can they be compatible? International Journal of Education Development, 23 (2), 167-185.

Barros, R., Mendonca, R., and Velazco, T. (1994). Is poverty the main cause of child work in urban Brazil? IPEA Discussion Paper No.351.

Basu, A.M. (1993). Family size and child welfare in an urban slum: some disadvantages of being poor but modern. In Cynthia B. Lloyd (Ed.), Fertility, family size and structure, NY: Population Council.

Basu, K. (1999). Child labor: Causes, consequences, and cure, with remarks on international labour standards. Journal of Economic Literature, 37, 1083-1119.

Basu, K., Das, S., \& Dutta, B. (2003). Birth order, gender and wealth as determinants of child labour: An empirical study of the Indian experience, mimeo.

Bhalotra, S., \& Heady, C. (2003). Child farm labour: The wealth paradox. Social Protection Discussion Paper No.20, The World Bank.

Chandrashekkar, C. P. (1997). The economic consequences of the abolition of child labour: An Indian case study. Journal of Peasant Studies, 24 (3), 137-179.

Cigno, A., Rosati, F. C., \& Guarcello, L. (2002). Does globalisation increase child labour?, IZA Discussion paper No. 470, Bonn.

Datt, G., \& Ravallion, M. (1998). Why have some Indian states done better than others at reducing rural poverty?, Economica, 65 (257), 17-38.

Dreze, J., \& Gazdar, H. (1996). Uttar Pradesh: The burden of inertia, in Jean Dreze and Amartya Sen (eds.) Indian development (pp. 33-128). Delhi: Oxford University Press.

Government of India. (1998). Economic Survey.

Grootaert,C., \& Patrinos,H. (1999). (Eds.), The policy analysis of child labour: A comparative study. New York: St Martin's Press. 
Heywood, C. (1988). Childhood in nineteenth-century France: Work, health, and education among the classes populaires. New York: Cambridge University Press.

Horrell, S., \& Humphries, J. (1995). The exploitation of little children: Child labour and the family economy in the Industrial Revolution. Explorations in Economic History, 32 (4), 485-516.

International Labour Organization. (1996). Child labour today: Facts and figures. Geneva: ILO.

International Labour Organization. (2004). International Labour Statistics. Geneva: ILO.

Kak, S. (2004). Magnitude and profile of child labour in the 1999s: Evidence from the NSS data.

Social Scientist, 32 (1-2), 45-73.

Kambhampati, U. S., \& Rajan, R. (2004a). Does child work decrease with parental income?: The luxury axiom revisited in India. Centre for Institutional Performance Discussion Paper, University of Reading.

Kambhampati, U. S., \& Rajan, R. (2004b). The 'nowhere' children: Patriarchy and the role of girls in India's rural economy, Centre for Institutional Performance Discussion Paper, University of Reading, UK.

Lieten, G. K. (2002). Child labour in India, Economic and Political Weekly, 37 (52), 5190-5195.

Nardinelli, C. (1990). Child labour and the Industrial Revolution. Bloomington, IN: Indiana University Press.

Neri, M. C., and Thomas, M. (2001). Household responses to labour market shocks in Brazil, 19821999, mimeo.

Ray, R. (2000). Child labour, child schooling, and their interaction with adult labour: Empirical evidence for Peru and Pakistan. The World Bank Economic Review, 14 (2), 347-371.

Swaminathan, M. (1998). Economic growth and the persistence of child labour - Evidence from an Indian city. World Development, 26 (8), 1513-1528.

Torres, R. (nd). Eliminating child labour: The role of human capital investment, mimeo.

Weiner, M., (1991). The child and the state in India. Princeton: Princeton University Press. 


\section{END NOTES}

${ }^{1}$ This is often considered to be an underestimate with official figures not fully reflecting reality.

${ }^{2}$ Alternatively, if families send children out to work because the returns to education are low, then even if growth increases household incomes, it is unlikely to significantly decrease the number of children working in an economy.

${ }^{3} \mathrm{We}$ are grateful to one of the referees of this paper for this point.

${ }^{4}$ ILO conventions recommend a minimum age for admission to employment or work that must not be less than the age for completing compulsory schooling, and in any case not less than 15 years. Lower ages are permitted - generally in countries where economic and educational facilities are less well-developed. The minimum age is 14 years and 13 years for 'light work'. On the other hand the minimum age for hazardous work is higher at 18 years.

${ }^{5}$ Children who work and study or who do household chores and work are classified either within work or within school, depending on which they claim as their primary activity. Such a classification is useful because it enables us to consider the child's primary activities in binary terms. However, it does not allow us to consider children who are multi-tasking. This does not seem to be a major problem in our sample because summary statistics indicate that a majority of the children ( $85 \%$ of boys and $71 \%$ of girls) who did some work worked full time i.e. 7 days a week.

${ }^{6}$ We use total household expenditure rather than household income as income tends to be rather unreliable in such surveys. People are less willing to indicate what their income is, often incomes in kind are excluded. Household expenditure also provides a 'lifecycle measure' of the household's income.

${ }^{7}$ As indicated earlier, we also included the household's land ownership as a separate variable. This captures the supply and demand aspects from a household point of view whereas the state agricultural proportion reflects demand for child workers in the economy more generally 
Table 1: Trends in Labour Participation Rates of Children (10-14 year olds)

\begin{tabular}{|l|c|c|}
\hline Region & $\mathbf{1 9 5 0}$ & $\mathbf{2 0 0 0}$ \\
\hline World & 27.49 & 11.24 \\
\hline Africa & 38.6 & 24.98 \\
\hline Latin America and Caribbean & 19.39 & 8.21 \\
\hline Asia & 36.05 & 10.2 \\
\hline Europe & 6.5 & 0.03 \\
\hline North America & 1.63 & 0 \\
\hline Oceania & 12.12 & 4.66 \\
\hline India & 35.43 & 12.07 \\
\hline China & 47.85 & 7.86 \\
\hline
\end{tabular}

Source: ILO, Labour Statistics, 2004.

Table 2: Macroeconomic Performance and Child Labour Participation Rates Across States in India, 1993

\begin{tabular}{|c|c|c|c|c|c|c|c|c|c|}
\hline \multirow{3}{*}{ States } & \multirow{3}{*}{$\begin{array}{l}\text { State } \\
\text { Per } \\
\text { Capita } \\
\text { NDP } \\
(1992)^{a}\end{array}$} & \multirow{3}{*}{$\begin{array}{l}\text { Growth Rate } \\
(1982-93)^{b}\end{array}$} & \multirow{3}{*}{$\begin{array}{l}\text { Poverty } \\
\text { Reduction }^{c}\end{array}$} & \multicolumn{3}{|c|}{$\begin{array}{l}\% \text { of children in work } \\
(1994)^{\mathrm{d}}\end{array}$} & \multicolumn{3}{|c|}{$\begin{array}{l}\text { \% of children in school } \\
(1994)^{\mathrm{e}}\end{array}$} \\
\hline & & & & & & & & & \\
\hline & & & & All & Boys & Girls & All & Boys & Girls \\
\hline ANDHRA PRADESH & 7650.8 & 32.22 & -3.68 & 17.27 & 18.16 & 16.32 & 60.84 & 68.49 & 53.05 \\
\hline BIHAR & 4275.0 & 12.74 & -1.96 & 4.11 & 5.66 & 2.05 & 54.36 & 62.84 & 43.10 \\
\hline GUJARAT & 11708.1 & 53.48 & -3.7 & 5.92 & 7.40 & 4.28 & 67.37 & 74.51 & 59.44 \\
\hline HARYANA & 12085.0 & 36.00 & -4.03 & 2.38 & 3.66 & 0.88 & 75.20 & 81.92 & 67.38 \\
\hline KARNATAKA & 8260.2 & 43.85 & -1.1 & 11.55 & 12.87 & 10.20 & 69.38 & 74.37 & 64.23 \\
\hline KERALA & 8132.1 & 32.80 & -4.06 & 0.92 & 0.95 & 0.89 & 93.77 & 93.56 & 93.98 \\
\hline MADHYA PRADESH & 6988.3 & 21.19 & -1.68 & 8.70 & 10.68 & 6.30 & 56.03 & 64.06 & 46.30 \\
\hline MAHARASHTRA & 12573.5 & 54.82 & -1.75 & 6.57 & 6.45 & 6.70 & 79.05 & 83.68 & 73.88 \\
\hline ORISSA & 5163.5 & 28.00 & -3.17 & 7.37 & 9.60 & 4.94 & 63.94 & 69.58 & 57.80 \\
\hline PUNJAB & 13770.5 & 35.08 & -4.03 & 4.28 & 7.24 & 0.80 & 76.55 & 80.55 & 71.84 \\
\hline RAJASTHAN & 7715.9 & 53.88 & -1.25 & 12.68 & 9.41 & 16.71 & 56.11 & 73.22 & 34.95 \\
\hline TAMILNADU & 9287.3 & 54.02 & -2.33 & 11.14 & 9.63 & 12.76 & 78.45 & 82.84 & 73.74 \\
\hline UTTAR PRADESH & 5892.3 & 20.42 & -2.08 & 4.59 & 6.20 & 2.61 & 61.08 & 71.13 & 48.79 \\
\hline WEST BENGAL & 7101.2 & 34.68 & -2.24 & 4.92 & 7.17 & 2.53 & 66.98 & 70.35 & 63.39 \\
\hline
\end{tabular}

Source:

${ }^{a}$ Per Capita State Domestic product at constant prices (SNDP) figures are computed from Datt and Ravalion, World

Bank Data Base

${ }^{\mathrm{b}}$ Simple Growth rate of states over a period of 10 years (1982-92) at constant prices using data from Datt and

Ravallion, World Bank Data Base

${ }^{\mathrm{c}}$ Poverty Reduction has been computed using (Datt \& Ravallion, 1998)

${ }^{\mathrm{d}, \mathrm{e}}$ Computed from NSSO data 
Table 3: Results for Child Schooling \& Work: All, Boys and Girls

\begin{tabular}{|c|c|c|c|c|c|c|c|c|c|c|c|c|}
\hline \multirow[b]{3}{*}{ |Variable } & \multicolumn{6}{|c|}{ Model Results } & \multicolumn{6}{|c|}{ Marginal Effects } \\
\hline & \multicolumn{2}{|c|}{ ALL } & \multicolumn{2}{|c|}{ BOYS } & \multicolumn{2}{|c|}{ GIRLS } & \multicolumn{2}{|c|}{ All } & \multicolumn{2}{|c|}{ Boys } & \multicolumn{2}{|c|}{ Girls } \\
\hline & Coefficient & t-ratio & Coefficient & t-ratio & Coefficient & t-ratio & Coefficient & t-ratio & Coefficient & t-ratio & Coefficient & t-ratio \\
\hline \multicolumn{13}{|l|}{ SCHOOL } \\
\hline Constant & -3.129 & -25.410 & -3.812 & -22.167 & -3.114 & -17.393 & 0 & & 0 & & 0 & \\
\hline AGE & 0.679 & 54.508 & 0.797 & 45.989 & 0.593 & 32.333 & 0.259 & 59.680 & 0.263 & 50.381 & 0.249 & 34.683 \\
\hline AGE2 & -0.035 & -55.353 & -0.039 & -45.102 & -0.032 & -34.884 & -0.013 & -58.025 & -0.012 & -46.768 & -0.013 & -36.330 \\
\hline PERSEX & -0.491 & -39.032 & & & & & -0.190 & -42.979 & & & & \\
\hline FEDUPRI & 0.120 & 7.239 & 0.155 & 6.376 & 0.115 & 4.900 & 0.036 & 6.641 & 0.037 & 5.568 & 0.042 & 4.776 \\
\hline FEDUSEC & 0.396 & 18.834 & 0.407 & 12.984 & 0.409 & 14.003 & 0.118 & 19.599 & 0.095 & 13.446 & 0.146 & 14.518 \\
\hline FEDUTER & 0.570 & 13.848 & 0.527 & 8.529 & 0.631 & 11.261 & 0.159 & 16.293 & 0.116 & 9.816 & 0.213 & 13.122 \\
\hline FATHER_WORK & 0.148 & 8.317 & 0.145 & 5.865 & 0.162 & 6.168 & 0.052 & 8.091 & 0.046 & 5.944 & 0.064 & 6.124 \\
\hline MEDUPRI & 0.307 & 11.287 & 0.308 & 7.671 & 0.274 & 7.066 & 0.089 & 10.966 & 0.070 & 7.302 & 0.096 & 6.885 \\
\hline MEDUSEC & 0.583 & 15.512 & 0.562 & 9.917 & 0.567 & 10.696 & 0.163 & 18.260 & 0.126 & 11.865 & 0.193 & 11.910 \\
\hline MEDUTER & 0.440 & 4.065 & 0.520 & 3.187 & 0.343 & 2.272 & 0.127 & 4.484 & 0.115 & 3.695 & 0.120 & 2.343 \\
\hline MOTHER_WORK & 0.103 & 3.486 & 0.205 & 4.642 & 0.041 & 0.985 & 0.040 & 4.171 & 0.058 & 5.389 & 0.025 & 1.611 \\
\hline HINDU & -0.038 & -1.198 & 0.091 & 2.023 & -0.145 & -3.227 & -0.015 & -1.401 & 0.019 & 1.440 & -0.052 & -3.064 \\
\hline MUSLIM & -0.394 & -10.915 & -0.329 & -6.401 & -0.457 & -8.772 & -0.155 & -11.215 & -0.112 & -6.380 & -0.184 & -9.099 \\
\hline SOCGRP & -0.330 & -25.841 & -0.335 & -18.872 & -0.336 & -17.774 & -0.113 & -24.447 & -0.100 & -18.060 & -0.129 & -17.271 \\
\hline DEBT & -0.164 & -9.681 & -0.157 & -6.736 & -0.173 & -6.827 & -0.054 & -8.816 & -0.045 & -6.216 & -0.064 & -6.355 \\
\hline FEMILIT & -0.200 & -9.454 & -0.074 & -3.261 & -0.696 & -13.976 & -0.074 & -9.462 & -0.023 & -3.207 & -0.278 & -13.979 \\
\hline MALEILI & -0.360 & -28.793 & -0.360 & -15.514 & -0.304 & -19.178 & -0.133 & -28.753 & -0.117 & -15.535 & -0.122 & -19.174 \\
\hline LAND & 0.046 & 1.465 & 0.060 & 1.323 & 0.047 & 1.008 & 0.015 & 1.352 & 0.018 & 1.342 & 0.016 & 0.907 \\
\hline PARWAGE1 & 0.000359 & 9.389 & 0.00028 & 4.864 & 0.00045 & 8.732 & 0.000 & 8.005 & $.57 \mathrm{D} 04$ & 3.338 & 0.000 & 8.362 \\
\hline OTHINCOM & 0.000104 & 32.176 & 0.00011 & 24.774 & 0.00010 & 23.037 & $.34 \mathrm{D} 04$ & 28.928 & $.30 \mathrm{D} 04$ & 21.870 & $.38 \mathrm{D} 04$ & 21.210 \\
\hline DEP & 1.035 & 14.884 & 0.763 & 7.858 & 1.457 & 14.151 & 0.360 & 15.198 & 0.220 & 8.011 & 0.575 & 14.466 \\
\hline VILPROS & 0.001 & 14.764 & 0.001 & 8.761 & 0.001 & 12.551 & 0.000 & 13.616 & 0.000 & 7.629 & 0.000 & 12.161 \\
\hline PCNDP92 & 0.000004 & 10.074 & 0.0000035 & 5.435 & 0.0000058 & 9.006 & $.13 \mathrm{D} 05$ & 8.691 & $.92 \mathrm{D} 06$ & 4.969 & $.19 \mathrm{D} 05$ & 7.665 \\
\hline GROWTH & 0.026 & 8.962 & 0.009 & 2.166 & 0.046 & 10.868 & 0.011 & 11.184 & 0.005 & 3.962 & 0.020 & 12.134 \\
\hline
\end{tabular}




\begin{tabular}{|c|c|c|c|c|c|c|c|c|c|c|c|c|}
\hline GROWTH2 & 0.00021 & -10.160 & -0.00005 & -1.751 & -0.00039 & -12.892 & $-0.84 \mathrm{D} 04$ & -11.870 & $-0.28 \mathrm{D} 04$ & -3.366 & 0.000 & -13.757 \\
\hline PROAGRI & -0.017 & -15.555 & -0.006 & -3.867 & -0.029 & -18.399 & -0.006 & -15.419 & -0.001 & -3.373 & -0.012 & -18.948 \\
\hline PRO-POOR & 0.029 & 3.560 & 0.015 & 1.278 & 0.038 & 3.235 & 0.011 & 3.768 & 0.004 & 1.186 & 0.016 & 3.521 \\
\hline \multicolumn{13}{|l|}{ WORK } \\
\hline Constant & -5.012 & -20.480 & -4.123 & -13.660 & -6.455 & -15.914 & 0 & & 0 & & 0 & \\
\hline $\mathrm{AGE}$ & 0.206 & 6.556 & 0.085 & 2.127 & 0.406 & 8.002 & 0.098 & 24.735 & 0.1410 & 20.687 & 0.073 & 16.709 \\
\hline AGE2 & 0.002 & 1.695 & 0.009 & 5.086 & -0.008 & -3.739 & -0.003 & -14.156 & -0.0035 & -10.917 & -0.002 & -11.928 \\
\hline PERSEX & -0.194 & -11.211 & & & & & -0.081 & -18.656 & & & & \\
\hline FEDUPRI & -0.175 & -7.642 & -0.222 & -7.338 & -0.105 & -2.882 & -0.020 & -6.147 & -0.0333 & -5.8380 & -0.007 & -1.822 \\
\hline FEDUSEC & -0.462 & -14.213 & -0.500 & -12.337 & -0.390 & -7.148 & -0.041 & -10.758 & -0.0603 & -9.4430 & -0.022 & -5.086 \\
\hline FEDUTER & -0.633 & -7.779 & -0.673 & -7.204 & -0.568 & -4.240 & -0.048 & -6.283 & -0.0732 & -6.4780 & -0.027 & -3.133 \\
\hline FATHER_WORK & -0.076 & -3.120 & -0.087 & -2.776 & -0.058 & -1.510 & -0.001 & -0.316 & -0.0017 & -0.2480 & 0.000 & 0.035 \\
\hline MEDUPRI & -0.515 & -13.526 & -0.499 & -9.948 & -0.443 & -7.017 & -0.051 & -13.880 & -0.0681 & -9.9530 & -0.029 & -7.228 \\
\hline MEDUSEC & -0.650 & -10.722 & -0.579 & -6.593 & -0.652 & -6.508 & -0.050 & -8.853 & -0.0550 & -3.7330 & -0.034 & -6.584 \\
\hline MEDUTER & -0.488 & -2.232 & -0.569 & -1.366 & -0.446 & -1.620 & -0.040 & -1.698 & -0.0573 & -0.8520 & -0.027 & -1.713 \\
\hline MOTHER_WORK & 0.071 & 1.910 & -0.122 & -2.238 & 0.238 & 4.291 & 0.026 & 3.488 & -0.0010 & -0.0870 & 0.037 & 4.037 \\
\hline HINDU & -0.030 & $\begin{array}{l}-0.699 \\
\end{array}$ & -0.159 & -2.869 & 0.195 & 2.478 & $\begin{array}{l}-0.009 \\
\end{array}$ & -1.240 & -0.0305 & -2.3260 & 0.015 & 2.029 \\
\hline MUSLIM & -0.012 & -0.220 & 0.021 & 0.316 & 0.003 & 0.037 & -0.029 & -4.390 & -0.0348 & -3.0390 & -0.015 & -1.899 \\
\hline SOCGRP & 0.248 & 14.153 & 0.275 & 12.260 & 0.223 & 7.763 & 0.018 & 5.872 & 0.0249 & 4.9030 & 0.012 & 3.470 \\
\hline DEBT & 0.168 & 7.475 & 0.149 & 5.130 & 0.190 & 5.270 & 0.018 & 4.314 & 0.0171 & 2.5240 & 0.016 & 3.338 \\
\hline LAND & -0.055 & -1.334 & -0.036 & -0.662 & -0.077 & -1.121 & -0.006 & -0.911 & -0.0001 & -0.0050 & -0.007 & -0.871 \\
\hline PARWAGE & -0.0006 & -10.155 & -0.00064 & -8.150 & -0.00048 & -4.920 & $-0.80 \mathrm{D} 04$ & -7.728 & -0.0001 & -6.7470 & $-0.35 \mathrm{D} 04$ & -3.267 \\
\hline OTHINCOM & -0.00010 & -20.989 & -0.0001 & -15.654 & -0.00012 & -13.850 & $-0.10 \mathrm{D} 04$ & -10.821 & $-0.10 \mathrm{D} 04$ & -6.3590 & $-0.98 \mathrm{D} 05$ & -8.863 \\
\hline DEP & -0.507 & -5.810 & -0.549 & -4.962 & -0.277 & -1.832 & -0.003 & -0.198 & -0.0319 & -1.4960 & 0.032 & 1.938 \\
\hline VILPROS & -0.001 & -11.479 & -0.001 & -8.651 & -0.001 & -6.291 & 0.000 & -7.426 & -0.0002 & -5.9340 & $-0.66 \mathrm{D} 04$ & -3.683 \\
\hline PCNDP92 & -0.0000075 & -11.423 & -0.0000045 & -5.545 & -0.000013 & -10.991 & $-0.997 \mathrm{D} 06$ & -8.952 & $-0.68 \mathrm{D} 06$ & -3.8480 & $-0.13 \mathrm{D} 05$ & -9.163 \\
\hline GROWTH & 0.041 & 9.326 & 0.037 & 6.686 & 0.060 & 8.140 & 0.010 & 12.246 & 0.0110 & 8.3100 & 0.009 & 9.600 \\
\hline GROWTH2 & -0.00019 & -6.235 & -0.00023 & -6.018 & -0.00024 & -4.731 & $-0.53 \mathrm{D} 04$ & -9.800 & $-0.68 \mathrm{D} 04$ & -7.5580 & $-0.44 \mathrm{D} 04$ & -7.288 \\
\hline PROAGRI & 0.011 & 6.655 & 0.009 & 4.367 & -0.002 & -0.632 & 0.001 & 1.950 & 0.0014 & 3.3710 & -0.001 & -4.253 \\
\hline PRO-POOR & -0.001 & -0.061 & -0.018 & -1.288 & 0.031 & 1.809 & 0.002 & 1.357 & -0.0026 & -0.8410 & 0.005 & 2.741 \\
\hline $\mathrm{RHO}(1,2)$ & -0.984 & -280.14 & -0.994 & -409.205 & -0.945 & -29.272 & & & & & & \\
\hline Log likelihood fn. & -40588.220 & & -19789.10 & & -20008.14 & & & & & & & \\
\hline
\end{tabular}


Table 4: Predicted Probabilities by State

\begin{tabular}{|l|c|c|c|c|c|c|}
\hline & \multicolumn{3}{|c}{ School } & \multicolumn{3}{c|}{ Work } \\
& ALL & Girls & Boys & ALL & Girls & Boys \\
\hline General & 0.716 & 0.645 & 0.767 & 0.026 & 0.020 & 0.028 \\
\hline Andhra Pradesh & 0.653 & 0.576 & 0.721 & 0.034 & 0.031 & 0.038 \\
\hline Bihar & 0.539 & 0.387 & 0.648 & 0.016 & 0.007 & 0.024 \\
\hline Gujarat & 0.784 & 0.717 & 0.833 & 0.025 & 0.032 & 0.021 \\
\hline Haryana & 0.745 & 0.620 & 0.832 & 0.023 & 0.011 & 0.025 \\
\hline Karnataka & 0.671 & 0.575 & 0.759 & 0.041 & 0.037 & 0.040 \\
\hline Kerala & 0.898 & 0.904 & 0.898 & 0.005 & 0.004 & 0.008 \\
\hline Madhya Pradesh & 0.632 & 0.529 & 0.706 & 0.027 & 0.016 & 0.037 \\
\hline Maharashtra & 0.808 & 0.750 & 0.859 & 0.018 & 0.023 & 0.016 \\
\hline Orissa & 0.564 & 0.427 & 0.676 & 0.042 & 0.032 & 0.046 \\
\hline Punjab & 0.827 & 0.766 & 0.863 & 0.009 & 0.001 & 0.016 \\
\hline Rajasthan & 0.554 & 0.308 & 0.756 & 0.072 & 0.102 & 0.038 \\
\hline Tamil Nadu & 0.778 & 0.731 & 0.821 & 0.032 & 0.046 & 0.000 \\
\hline Uttar Pradesh & 0.628 & 0.497 & 0.722 & 0.025 & 0.014 & 0.031 \\
\hline West Bengal & 0.704 & 0.651 & 0.751 & 0.030 & 0.033 & 0.031 \\
\hline
\end{tabular}

Note: Predicted probabilities are calculated with all variables being held at state-level mean values, except those for the scenario under consideration in each case.

Table 5: Predicted Probabilities by variables

\begin{tabular}{|l|c|c|c|c|c|c|}
\hline & \multicolumn{3}{|c|}{ School } & \multicolumn{3}{c|}{ Work } \\
\hline & ALL & GIRLS & BOYS & ALL & GIRLS & BOYS \\
\hline General & 0.676 & 0.574 & 0.755 & 0.026 & 0.020 & 0.028 \\
\hline PCNDP = max & 0.768 & 0.704 & 0.817 & 0.008 & 0.002 & 0.015 \\
\hline PCNDP = min & 0.618 & 0.495 & 0.716 & 0.046 & 0.057 & 0.040 \\
\hline GROWTH = max & 0.608 & 0.408 & 0.767 & 0.063 & 0.103 & 0.033 \\
\hline GROWTH = min & 0.654 & 0.552 & 0.730 & 0.007 & 0.002 & 0.015 \\
\hline PROAGRI = max & 0.593 & 0.422 & 0.730 & 0.036 & 0.019 & 0.036 \\
\hline PROAGRI = min & 0.754 & 0.719 & 0.780 & 0.018 & 0.022 & 0.021 \\
\hline PRO-POOR = max & 0.694 & 0.599 & 0.763 & 0.026 & 0.023 & 0.026 \\
\hline PRO-POOR = min & 0.663 & 0.555 & 0.749 & 0.026 & 0.018 & 0.030 \\
\hline
\end{tabular}

Note: Predicted probabilities are calculated with all variables being held at state-level mean values, except those for the scenario under consideration in each case.

Table 6: Results for Child Schooling \& Work: with Growth * NDP

\begin{tabular}{|c|c|c|c|c|c|c|}
\hline & ALL & & BOYS & & GIRLS & \\
\hline \multirow[t]{2}{*}{ Variable } & Coefficient & t-ratio & Coefficient & t-ratio & Coefficient & t-ratio \\
\hline & \multicolumn{2}{|c|}{ SCHOOL } & \multicolumn{2}{|c|}{ SCHOOL } & \multicolumn{2}{|c|}{ SCHOOL } \\
\hline Constant & -2.652 & -26.164 & -3.592 & -24.888 & -2.286 & -15.610 \\
\hline $\mathrm{AGE}$ & 0.681 & 54.620 & 0.797 & 45.840 & 0.598 & 32.593 \\
\hline AGE2 & -0.035 & -55.501 & -0.039 & -44.953 & -0.032 & -35.142 \\
\hline PERSEX & -0.490 & -38.768 & & & & \\
\hline FEDUPRI & 0.132 & 7.925 & 0.164 & 6.729 & 0.128 & 5.425 \\
\hline FEDUSEC & 0.387 & 18.379 & 0.393 & 12.506 & 0.401 & 13.711 \\
\hline FEDUTER & 0.583 & 14.105 & 0.533 & 8.540 & 0.645 & 11.502 \\
\hline FATHER_WORK & 0.163 & 9.100 & 0.154 & 6.194 & 0.183 & 6.919 \\
\hline
\end{tabular}




\begin{tabular}{|c|c|c|c|c|c|c|}
\hline MEDUPRI & 0.310 & 11.357 & 0.307 & 7.606 & 0.276 & 7.161 \\
\hline MEDUSEC & 0.581 & 15.490 & 0.549 & 9.716 & 0.568 & 10.779 \\
\hline MEDUTER & 0.449 & 4.159 & 0.501 & 3.094 & 0.365 & 2.401 \\
\hline MOTHER_WORK & 0.103 & 3.484 & 0.204 & 4.594 & 0.036 & 0.877 \\
\hline HINDU & 0.014 & 0.448 & 0.137 & 3.061 & -0.086 & -1.918 \\
\hline MUSLIM & -0.346 & -9.620 & -0.289 & -5.644 & -0.401 & -7.715 \\
\hline SOCGRP & -0.311 & -24.238 & -0.316 & -17.727 & -0.315 & -16.650 \\
\hline DEBT & -0.169 & -9.991 & -0.157 & -6.709 & -0.186 & -7.311 \\
\hline FEMILIT & -0.198 & -9.282 & -0.076 & -3.333 & -0.683 & -13.802 \\
\hline MALEILI & -0.364 & -29.146 & -0.368 & -15.804 & -0.311 & -19.750 \\
\hline LAND & 0.051 & 1.634 & 0.064 & 1.408 & 0.050 & 1.083 \\
\hline PARWAGE & 0.000 & 9.052 & 0.000 & 4.760 & 0.000 & 8.346 \\
\hline OTHINCOM & 0.000 & 34.142 & 0.000 & 25.605 & 0.000 & 24.959 \\
\hline DEP & 1.020 & 14.617 & 0.746 & 7.627 & 1.442 & 14.004 \\
\hline VILPROS & 0.001 & 14.628 & 0.001 & 8.587 & 0.001 & 12.505 \\
\hline PCNDP & 0.000 & 10.932 & 0.000 & 9.065 & 0.000 & 6.343 \\
\hline GROWTH*NDPL & -0.004 & -6.961 & -0.001 & -1.501 & -0.008 & -8.302 \\
\hline GROWTH*NDPM & -0.003 & -3.455 & -0.003 & -2.653 & -0.003 & -2.246 \\
\hline GROWTH*NDPH & -0.006 & -6.895 & -0.006 & -4.458 & -0.007 & -5.298 \\
\hline PROAGRI & -0.011 & -7.598 & -0.010 & -4.772 & -0.013 & -6.104 \\
\hline \multirow[t]{2}{*}{ PRO-POOR } & 0.072 & 8.998 & 0.035 & 3.080 & 0.105 & 9.227 \\
\hline & \multicolumn{2}{|c|}{ WORK } & \multicolumn{2}{|c|}{ WORK } & \multicolumn{2}{|c|}{ WORK } \\
\hline Constant & -4.790 & -22.410 & -3.772 & -13.757 & -6.279 & -17.729 \\
\hline AGE & 0.196 & 6.311 & 0.076 & 1.887 & 0.398 & 7.890 \\
\hline AGE2 & 0.003 & 2.032 & 0.009 & 5.220 & -0.008 & -3.568 \\
\hline PERSEX & -0.186 & -10.626 & & & & \\
\hline FEDUPRI & -0.166 & -7.192 & -0.217 & -7.097 & -0.096 & -2.662 \\
\hline FEDUSEC & -0.456 & -14.096 & -0.499 & -12.320 & -0.380 & -6.945 \\
\hline FEDUTER & -0.610 & -7.245 & -0.649 & -6.491 & -0.549 & -4.327 \\
\hline FATHER_WORK & -0.067 & -2.735 & -0.081 & -2.561 & -0.041 & -1.056 \\
\hline MEDUPRI & -0.522 & -13.401 & -0.504 & -9.543 & -0.459 & -7.429 \\
\hline MEDUSEC & -0.667 & -11.232 & -0.580 & -6.749 & -0.682 & -6.898 \\
\hline MEDUTER & -0.468 & -2.129 & -0.537 & -1.342 & -0.391 & -1.471 \\
\hline MOTHER_WORK & 0.078 & 2.080 & -0.110 & -1.957 & 0.231 & 4.216 \\
\hline HINDU & -0.050 & -1.129 & -0.189 & -3.371 & 0.188 & 2.351 \\
\hline MUSLIM & -0.020 & -0.386 & -0.002 & -0.028 & 0.006 & 0.065 \\
\hline SOCGRP & 0.252 & 14.174 & 0.269 & 11.871 & 0.239 & 8.271 \\
\hline DEBT & 0.155 & 6.844 & 0.139 & 4.737 & 0.167 & 4.605 \\
\hline LAND & -0.021 & -0.513 & 0.002 & 0.036 & -0.046 & -0.670 \\
\hline PARWAGE & -0.001 & -10.108 & -0.001 & -8.109 & 0.000 & -4.994 \\
\hline OTHINCOM & 0.000 & -20.743 & 0.000 & -15.585 & 0.000 & -13.349 \\
\hline DEP & -0.504 & -5.663 & -0.508 & -4.416 & -0.323 & -2.135 \\
\hline VILPROS & -0.001 & -11.080 & -0.001 & -8.354 & -0.001 & -6.252 \\
\hline PCNDP92 & 0.000 & -14.284 & 0.000 & -10.040 & 0.000 & -10.806 \\
\hline GROWTH*NDPL & 0.018 & 19.760 & 0.009 & 7.859 & 0.029 & 19.533 \\
\hline GROWTH*NDPM & 0.024 & 20.175 & 0.016 & 10.693 & 0.036 & 18.274 \\
\hline GROWTH*NDPH & 0.023 & 17.380 & 0.016 & 9.618 & 0.033 & 14.865 \\
\hline PROAGRI & 0.027 & 12.973 & 0.027 & 10.221 & 0.019 & 5.105 \\
\hline PRO-POOR & 0.022 & 2.133 & 0.006 & 0.451 & 0.060 & 3.642 \\
\hline $\mathrm{RHO}(1,2)$ & -0.985 & -274.906 & -0.993 & -351.737 & -0.958 & -39.354 \\
\hline
\end{tabular}


Appendix 1a: Data Description of Dummy Variables in the Model.

\begin{tabular}{|c|c|c|c|c|c|}
\hline Dummy Variables & Description & No: of $1 \mathrm{~s}$ & Prop. Of 1s & Missing & NOBS \\
\hline SCHOOL & $\begin{array}{l}\text { Identifies the primary activity of the child; coded } 1 \text { if the primary activity is } \\
\text { stated to be work, else coded } 0 \\
\text { (1=primary activity is attending school) }\end{array}$ & 49302 & $64.85 \%$ & - & 76027 \\
\hline SEX & Gender of the child, coded 1=Girls $0=$ Boys; $(1=$ Girl $)$ & 35243 & $46.41 \%$ & 12 & 76015 \\
\hline FEDUPRI & Father's primary Education; coded, $1=$ primary education else $=0$ & 10960 & $14.43 \%$ & \multirow{2}{*}{84} & \multirow{2}{*}{75943} \\
\hline FEDUTER & Father's tertiary education; coded $1=$ tertiary education else coded 0 & 2221 & $2.90 \%$ & & \\
\hline FATHER_WORK & $\begin{array}{l}\text { Father's employment; Binary variable coded } 0=\text { No work, else } 1 \\
\text { (employed=1) } \\
\text { Q: If the principal activity of the father was working, did he work more or less } \\
\text { regularly in the last } 365 \text { days? }\end{array}$ & 63669 & $89.6 \%$ & 4949 & 71078 \\
\hline MEDUPRI & Mother's primary Education; coded, $1=$ primary education else $=0$ & 4804 & $7.32 \%$ & \multirow{2}{*}{9402} & \multirow{2}{*}{66625} \\
\hline MEDUSEC & ,Mother's secondary education; coded, $1=$ secondary education else coded 0 & 3385 & $5.1 \%$ & & \\
\hline MOTHER_WORK & $\begin{array}{l}\text { Mother's employment; coded } 0=\text { No work, else } 1 \\
\text { (employed=1) } \\
\text { Q: The principal activity status of the mother }\end{array}$ & 23116 & $34.7 \%$ & 9390 & 66637 \\
\hline HINDU & $\begin{array}{l}\text { Religion of the household: coded Hindu=1, else } 0 \\
(\text { Hindu=1) }\end{array}$ & 64014 & $84.2 \%$ & - & 76027 \\
\hline MUSLIM & $\begin{array}{l}\text { Religion of the household: coded Muslim=1, else } 0 \\
\text { (Muslim=1) }\end{array}$ & 8101 & $10.7 \%$ & - & 76027 \\
\hline SOCGRP & Social Group of the household; $1=$ scheduled castes and tribes; $0=$ all others. & 21198 & 27.8 & & 21198 \\
\hline DEBT & $\begin{array}{l}\text { Household debt: coded } 0=\text { no debt, else }=1 . \\
\text { (if the household has debt=1) }\end{array}$ & 8863 & $11.6 \%$ & - & 76027 \\
\hline LAND & $\begin{array}{l}\text { Indicates whether households own any land; coded } 1 \text { if they posses any land else } \\
\text { coded } 0\end{array}$ & 73442 & $96.6 \%$ & - & 76027 \\
\hline
\end{tabular}


Appendix 1b: Descriptive Statistics for Continuous Variables

\begin{tabular}{|c|c|c|c|c|c|c|}
\hline Continuous Variables & Description & Mean & S.D & Minimum & Maximum & NOBS \\
\hline AGE & Age of the child & 9.768 & 3.13 & 5 & 15 & 76027 \\
\hline AGE2 & Age*Age & 104.28 & 62.82 & 25 & 225 & 76027 \\
\hline FEMILIT & $\begin{array}{l}\text { Household female illiteracy i.e. the number of females who are illiterate as a } \\
\text { proportion of all females in the household }\end{array}$ & 0.4 & 0.3 & 0 & 1 & 76027 \\
\hline MALEILIT & $\begin{array}{l}\text { Household male illiteracy i.e. the number of males who are illiterate as a } \\
\text { proportion of all males in the household }\end{array}$ & 0.60 & 0.52 & 0 & 6 & 76027 \\
\hline DEP & $\begin{array}{l}\text { Number of dependants in the household: this included those members below the } \\
\text { age of } 5 \text { and above the age of } 60 \mathrm{yrs}\end{array}$ & 1.05 & 1.2 & 0 & 10 & 76027 \\
\hline OTHINCOM & Household monthly expenditure-(mother wage+father wage+child wage) & 1846.17 & 2215.0 & -2933.0 & $375428.0^{8}$ & 76027 \\
\hline PARWAGE & Mother wage + father wage & 93.34 & 190.5 & 0 & 3700 & 70488 \\
\hline VILPROS & Average village wages (male \&female) & 132.48 & 94.86 & 0 & 802.39 & 68158 \\
\hline EXPEDU & $\begin{array}{l}\text { State expenditure on education (capital expenditure) as a proportion of the SGDP } \\
\text { (current prices) during the period 1985-92 }\end{array}$ & 0.48 & 0.3 & 0.1 & 0.9 & 76027 \\
\hline PROAGRI & State agriculture as a proportion of the SGDP (current prices) 1982-92 & 32.60 & 6.94 & 18.39 & 45.33 & 76027 \\
\hline SNDP & Per capita net state domestic product (constant prices) for 1992 & 75827.4 & 26196.738 & 42749.6 & 137705.3 & 76027 \\
\hline GROWTH & Simple Growth rate of states over a period of 10 years (1982-92) at constant prices & 62.43 & 17.48 & 37.81 & 97 & 76027 \\
\hline GROWTH*SNDPL & $\begin{array}{l}\text { Interactive term between Growth (1982-1992) and Percapita GDP (1982) for states } \\
\text { categorised as low growth. Per capita GDP was coded } 1 \text { if it was above } 37918 \text { and } \\
\text { below 50143, else was coded } 0 \text { and then this was interacted with Growth }\end{array}$ & 23.85 & & 0 & 97 & 76027 \\
\hline GROWTH*SNDPM & $\begin{array}{l}\text { Interactive term between Growth (1982-1992) and Percapita GDP (1982) for states } \\
\text { categorised as low growth. It was coded } 1 \text { if Per capita GDP was above } 50144 \text { and } \\
\text { below } 60298 \text {, else was coded } 0 \text { and then this was interacted with Growth }\end{array}$ & 24.05 & & 0 & 93.2 & 76027 \\
\hline GROWTH*SNDPH & $\begin{array}{l}\text { Interactive term between Growth (1982-1992) and Percapita GDP (1982) for states } \\
\text { categorised as low growth. It was coded } 1 \text { if Per capita GDP was above 60298, } \\
\text { else was coded } 0 \text { and then this was interacted with Growth }\end{array}$ & 14.52 & & 0 & 85.5 & 76027 \\
\hline PRO-POOR & $\begin{array}{l}\text { Correlation between Mean Consumption \& Squared Poverty Gap (Dutt \& } \\
\text { Ravallion, 1998) is -.691, which we set as the average for All India. Then we } \\
\text { computed a variable X, which gives the reduction in poverty across states for I unit } \\
\text { increase in mean consumption. PRO-POOR is the difference between the squared } \\
\text { poverty Gap and X. }\end{array}$ & 2.35 & .87 & 1.1 & 4.06 & 76027 \\
\hline
\end{tabular}

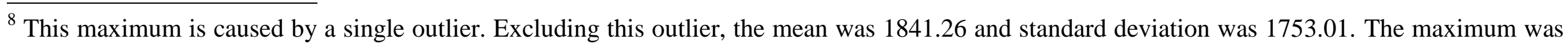
50609.72. 
